\title{
Changes in DNA, cyclic nucleotides and steroids during induced follicular atresia in the hamster
}

\author{
C. J. Hubbard and G. S. Greenwald \\ Department of Physiology, Ralph L. Smith Research Center, University of Kansas Medical \\ Center, Kansas City, Kansas 66103, U.S.A.
}

\begin{abstract}
Summary. Atresia was induced in antral follicles of hypophysectomized PMSG (30 i.u.)-treated hamsters by an i.p. injection of PMSG antiserum. Mature antral follicles were isolated and incubated for $1 \mathrm{~h}$. When expressed per follicle, cAMP increased $108 \%$ above control levels at $2 \mathrm{~h}$, while cGMP rose $117 \%$ at $4 \mathrm{~h}$; both nucleotides then declined (12-72 h). DNA per follicle fell below control values by $24 \mathrm{~h}$ and reached its lowest point at $48 \mathrm{~h}$. Serum concentrations of oestradiol-17及 and testosterone were $50 \%$ lower by $1 \mathrm{~h}$ after injections of PMSG antiserum. Oestradiol and testosterone in serum, incubation medium and tissue dropped rapidly to reach basal values by $12 \mathrm{~h}$. Serum progesterone showed a sharp increase at $4 \mathrm{~h}$ then dropped below control levels by $12 \mathrm{~h}$ and remained constant thereafter. In tissue and medium, progesterone rose to peak values at $8 \mathrm{~h}$, then dropped to control levels with no significant changes for the remaining $64 \mathrm{~h}$. The precipitous decreases in both oestradiol and testosterone in the serum, medium and tissue indicate inhibition of steroid synthesis at some point after progesterone formation.

These results demonstrate the usefulness of this model for following atretic changes in a synchronized population of Graafian follicles.
\end{abstract}

\section{Introduction}

One of the most important but unknown areas in ovarian function are the factors involved in follicular atresia. Over the past several years we have developed an animal model which produces a large number of mature antral follicles and ensures a very circumscribed 'time zero' for the induction of atresia: PMSG-primed hypophysectomized hamsters are injected with an antiserum to PMSG (Greenwald, 1963, 1973, 1979). The PMSG antiserum induces a more rapid removal of gonadotrophin (PMSG) than occurs if the hormone degrades normally and this also accelerates the atretic process.

Bill (1978) and Bill \& Greenwald (1979) have tested this model extensively. Hypophysectomized hamsters were injected with 30 i.u. PMSG on Day 1 (09:00 h, morning of ovulation) and PMSG antiserum was injected on Day $4(09: 00 \mathrm{~h})$. At $1 \mathrm{~h}$ after injection of antiserum, serum oestradiol dropped to $50 \%$ of control levels while progesterone remained essentially unchanged for $24 \mathrm{~h}$. By $4 \mathrm{~h}$, degenerative changes in the granulosa cells were detectable by light and electron microscopy. Bill (1978) also showed that, following PMSG treatment (omitting PMSG antiserum), serum oestradiol levels rose at Day 1 and were elevated until at least Day 5 while serum progesterone declined markedly. Serum PMSG concentrations rose and did not fall significantly from the peak value until Day 5. These studies indicate that the PMSG antiserum eliminated the effective circulating levels of PMSG when injected on Day 4. 
In these earlier studies (Bill, 1978; Bill \& Greenwald, 1979) the entire ovary was incubated in vitro. The purpose of the present study was to follow the changes in DNA, cyclic nucleotides and steroids in isolated atretic follicles in vitro after administration of antiserum to PMSG. DNA was analysed as an indicator of cell death during atresia. Cyclic nucleotides were measured because of their close link to gonadotrophin action.

\section{Animals}

\section{Materials and Methods}

Female hamsters (Mesocricetus auratus) weighing 80-120 g were maintained in $14 \mathrm{~h}$ light $(05: 00-19: 00 \mathrm{~h}) / 24 \mathrm{~h}$. The morning of ovulation, as evidenced by the copious vaginal discharge, was designated as Day 1 . The animals exhibited at least 3 cycles before treatment. The hamsters were hypophysectomized (6 animals per group) on Day $1(09: 00 \mathrm{~h})$ using a parapharyngeal approach. Immediately after surgery a subcutaneous injection of 30 i.u. PMSG (Pemex: Sankyo Co., Tokyo, Japan) was given. An intraperitoneal injection of $100 \mu \mathrm{l}$ antiserum to PMSG (see Bill, 1978) was given at 09:00 h on Day 4 and the animals were decapitated 1, 2, 4, 8, 12, 24, 48 or $72 \mathrm{~h}$ later. A control group of hypophysectomized PMSG-treated hamsters which received no antiserum was killed at 09:00 h on Day $4(0 \mathrm{~h})$. Antiserum to PMSG was raised in rabbits by Dr D. C. Johnson and has been previously characterized for the hamster by Bill (1978). Trunk blood was collected from each animal and serum was saved for radioimmunoassay of steroids. Both ovaries were immediately removed and large antral follicles were dissected free in cold saline (at $\left.4^{\circ} \mathrm{C}, 9 \mathrm{~g} \mathrm{NaCl} / \mathrm{l}\right)$ using pointed forceps and a 22 -gauge hypodermic needle. An average of 25 follicles was obtained from two ovaries and they were placed in $1 \mathrm{ml}$ Hanks' balanced salt solution (Grand Island Biological Co., Chagrin Falls, Ohio, U.S.A.) with 2 mM-2-methyl 5-isobutylxanthine (Sigma, St Louis, Missouri, U.S.A.), a phosphodiesterase inhibitor.

The effectiveness of the PMSG in sustaining follicular development beyond Day 4 was tested by injecting control animals with $100 \mu \mathrm{l}$ normal rabbit serum (NRS) at 09:00 h on Day 4. The animals were killed 12, 24, 48 and $72 \mathrm{~h}$ later. Trunk blood was collected and follicles were incubated as described above but without the addition of methyl isobutylxanthine. Oestradiol and progesterone were assayed in the serum and incubation medium because previous work (Bill, 1978) indicated that oestradiol was a sensitive indicator of follicular atresia while progesterone may reflect the status of the theca.

\section{Incubations}

Incubations were performed for $1 \mathrm{~h}$ at $37^{\circ} \mathrm{C}$ in a Dubnoff shaker bath after which the follicles were separated from the medium and homogenized in $1 \mathrm{ml} 5 \%$ trichloroacetic acid (TCA). The TCA suspension was centrifuged and the pellet washed three times with additional TCA. TCA supernatants were extracted three times with $5 \mathrm{ml}$ diethyl ether. The aqueous portion was then dried using a Searle vortex-evaporator at $60^{\circ} \mathrm{C}$, reconstituted with $0.05 \mathrm{M}$-sodium acetate buffer (pH 6.2) and assayed for adenosine $3^{\prime}: 5^{\prime}$ monophosphate (cAMP) and guanosine $3^{\prime}: 5^{\prime}$ monophosphate (cGMP). Part $(10 \mathrm{ml})$ of the ether extract from each sample was dried for steroid assay using the vortex evaporator and reconstituted with $1 \mathrm{ml}$ distilled water. Sodium bicarbonate was added to each steroid sample until $\mathrm{CO}_{2}$ ceased to be released indicating neutralization of the TCA.

Cyclic AMP and cGMP were determined using the radioimmunoassay method of Steiner, Parker \& Kipnis (1972) with kits supplied by New England Nuclear (Boston, Massachusetts, U.S.A.). The non-acetylated assays have a sensitivity between 0.1 and 25 pmol for cAMP and 0.05 and $10 \mathrm{pmol}$ for cGMP. Cross-reactivity between the two cyclic nucleotides was checked 
by adding twice the highest experimental concentration of one cyclic nucleotide to the standard curve concentrations of the other. Displacement of the curve was $<1 \%$ for both cyclic nucleotides. Assay specificity was determined by incubating experimental samples containing known concentrations of cyclic nucleotides with 0.026 i.u. beef heart cyclic nucleotide phosphodiesterase (Sigma: Lot $16 \mathrm{C}-9510$ ) in a $37^{\circ} \mathrm{C}$ water bath for $1 \mathrm{~h}$. When assayed, cGMP showed a $90 \%$ reduction in activity and cAMP concentrations decreased by $90-100 \%$. Column chromatography performed on experimental samples showed no difference between separated and unseparated samples. Serial dilutions of experimental samples assayed for both cyclic nucleotides showed a linear decline in concentration. Percentage recovery for both cyclic nucleotides was determined using $\left[{ }^{3} \mathrm{H}\right] \mathrm{cAMP}$ and $\left[{ }^{3} \mathrm{H}\right] \mathrm{cGMP}$ and found to be $95-100 \%$.

\section{Steroid assays}

Oestradiol-17 $\beta$, testosterone equivalents and progesterone were determined by radioimmunoassay using antisera to oestradiol (Exley, Johnson \& Dean, 1971), testosterone (Pang \& Johnson, 1974) and progesterone (Surve, Bacso, Brinkerhoff \& Kirsh, 1976). Since the antiserum to testosterone cross-reacts with $5 \alpha$-dihydrotestosterone $(58 \%)$ and androstenedione (2\%), testosterone is designated as androgen. The RIA procedures for steroid determinations of sera and media are described by Terranova \& Greenwald (1978). Steroid values from TCA extracts showed no differences when compared with those processed by the method of Terranova \& Greenwald (1978). TCA extracts neutralized by sodium bicarbonate did not interfere with the assay standards. Percentage recovery for tissue samples using internal standards $\left(\left[2,4,6,7-{ }^{3} \mathrm{H}\right]\right.$ oestradiol- $17 \beta ;\left[1,2,6,7-{ }^{3} \mathrm{H}\right]$ testosterone; $\left[1,2,6,7-{ }^{3} \mathrm{H}\right]$ progesterone) were $90 \cdot 5 \%$ for oestradiol, $95.0 \%$ for testosterone and $71.1 \%$ for progesterone. The lower limits of sensitivity for the assays were $2 \mathrm{pg}$ for oestradiol- $17 \beta$ and testosterone and $5 \mathrm{pg}$ for progesterone.

\section{DNA assay}

The pellet obtained following centrifugation of the TCA homogenate was suspended in 0.5 $\mathrm{N}$-perchloric acid and heated for $30 \mathrm{~min}$ at $70^{\circ} \mathrm{C}$ to extract DNA. After centrifugation of the extract, aliquots of supernatant were assayed for DNA according to the method of Giles \& Myers (1965). Serial dilutions of experimental DNA samples were linear. $<7 \%$.

Inter- and intra-assay coefficients of variation for DNA, cyclic nucleotides, and steroids were

\section{Statistics}

Statistical analysis consisted of one-way analysis of variance and Duncan's new multiple-range test. Significance was determined at the level of $P<0.05$.

\section{Results}

\section{Antiserum-treated hamsters}

The DNA content per follicle was unchanged until $24 \mathrm{~h}$ after the injection of antiserum (Text-fig. 1a). At $48 \mathrm{~h}$, DNA dropped precipitously followed by a slight but significant increase at $72 \mathrm{~h}$.

Cyclic AMP and cGMP (Text-fig. 1a) underwent opposing changes: between 2 and $4 \mathrm{~h}$ cAMP fell significantly from $3.03 \pm 0.02$ to $2.33 \pm 0.2 \mathrm{pmol} /$ follicle whereas cGMP increased from $1.73 \pm 0.2$ to $2.30 \pm 0.2 \mathrm{pmol} /$ follicle. Thereafter, both cyclic nucleotides declined. 


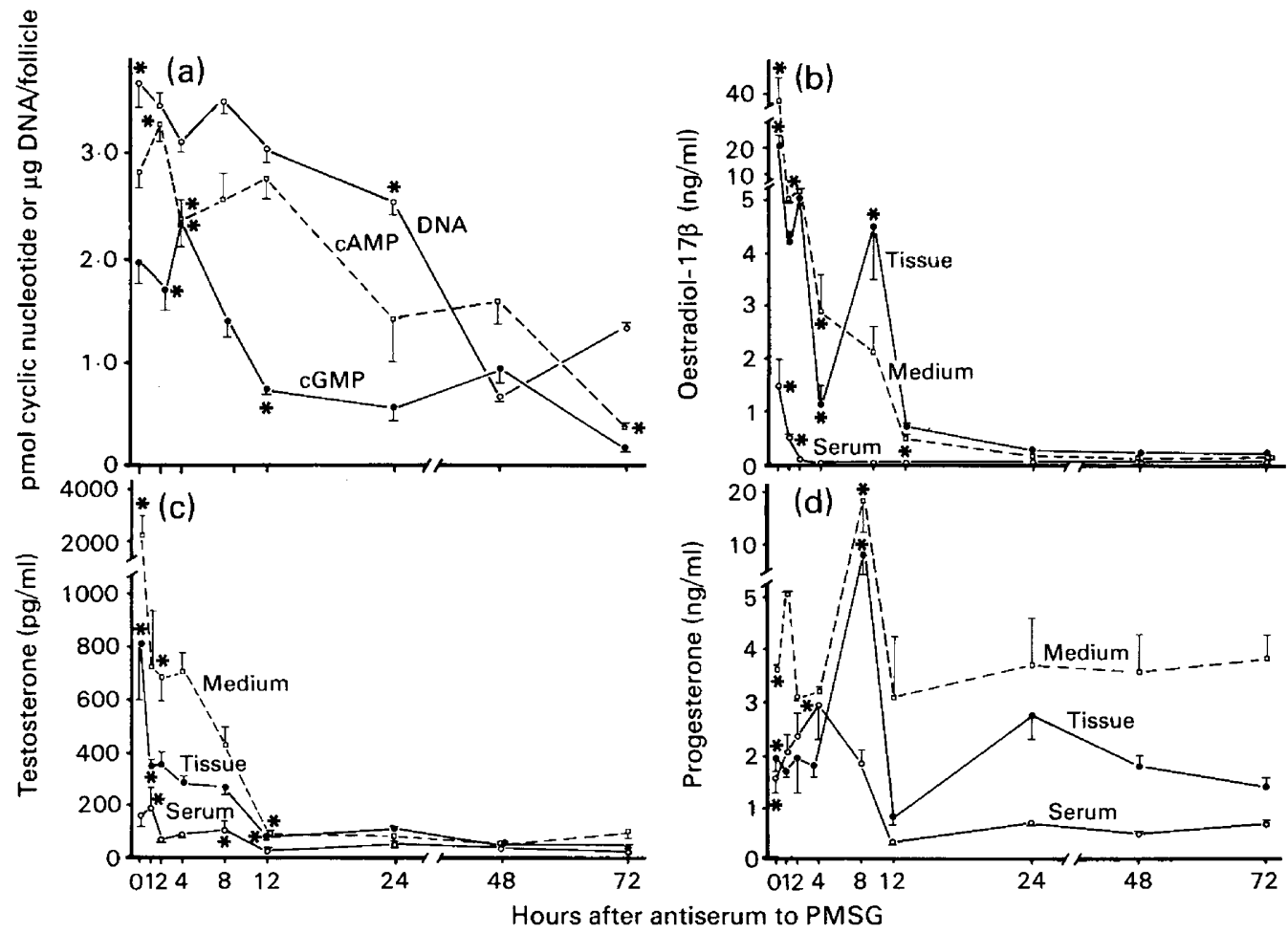

Text-fig. 1. The mean ( \pm s.e.m. for $>5$ observations) changes of (a) DNA, cAMP, cGMP, (b) oestradiol-17ß, (c) androgen and (d) progesterone in incubated antral follicles (a) and in serum, medium and tissue (b, c, d) taken from PMSG-primed hypophysectomized hamsters after injection of an antiserum to PMSG $(0 \mathrm{~h})$. *Values significantly different from each other for each substance measured.

Concentrations of oestradiol in serum, medium and tissue dropped significantly by $1 \mathrm{~h}$ and were basal by $12 \mathrm{~h}$ (Text-fig. $1 \mathrm{~b}$ ). In the medium, oestradiol increased slightly (non-significantly) at $2 \mathrm{~h}$ followed by a downward trend throughout the $72-\mathrm{h}$ period. Tissue oestradiol decreased in a stepwise manner, showing transient increases at 2 and $8 \mathrm{~h}$.

Serum androgen did not decline significantly until $2 \mathrm{~h}$ after antiserum injection (Text-fig. 1c). No significant changes occurred throughout the remaining period. Androgen in the medium and tissue decreased rapidly from $0 \mathrm{~h}$ to reach basal levels by $12 \mathrm{~h}$.

Table 1. Oestradiol and progesterone concentrations after i.p. injection of normal rabbit serum (NRS) at $0^{n}: 00 \mathrm{~h}$ on Day 4 to PMSG-primed hypophysectomized hamster (Day 1)

\begin{tabular}{|c|c|c|c|c|}
\hline \multirow{2}{*}{$\begin{array}{c}\text { Time after } \\
\text { NRS } \\
\text { (h) }\end{array}$} & \multicolumn{2}{|c|}{ Oestradiol (ng/ml) } & \multicolumn{2}{|c|}{ Progesterone $(\mathrm{ng} / \mathrm{ml})$} \\
\hline & Serum & $\begin{array}{l}\text { Incubation } \\
\text { medium }\end{array}$ & Serum & $\begin{array}{l}\text { Incubation } \\
\text { medium }\end{array}$ \\
\hline 12 & $* 1.10 \pm 0.21$ & $10.34 \pm 1.79$ & $2.92 \pm 0.63$ & $0.79+0.13$ \\
\hline 24 & $* 0.48 \pm 0.20$ & ${ }^{*} 6.53 \pm 1.61$ & $2.19 \pm 0.49$ & $*^{*} 1.02 \pm 0.11$ \\
\hline 48 & $0.24 \pm 0.15$ & $3.01 \pm 1.28$ & $2.20 \pm 0.56$ & $0.63 \pm 0.17$ \\
\hline 72 & $0.34 \pm 0.018$ & ${ }^{*} 0.12 \pm 0.017$ & $2.20 \pm 0.67$ & ${ }^{*} 0.49 \pm 0.05$ \\
\hline
\end{tabular}

*Values at different times within the same group significantly different from each other $(P<0.05)$. 
Serum levels of progesterone increased significantly by $4 \mathrm{~h}$ while medium and tissue values were elevated by $8 \mathrm{~h}$ (Text-fig. 1d). Following these transient increases, serum progesterone dropped and remained below control levels while medium and tissue values returned to control levels. A transient (non-significant) increase occurred in tissue progesterone at $24 \mathrm{~h}$.

\section{Hamsters injected with normal rabbit serum}

Table 1 shows that serum oestradiol remained high in these animals and the fall in the incubation medium occurred after $24 \mathrm{~h}$. Serum progesterone levels (Table 1) remained the same throughout the 72-h period while those in the medium fell significantly between 24 and $72 \mathrm{~h}$.

\section{Discussion}

When animals were injected with NRS instead of PMSG antiserum, oestradiol levels in the serum and medium remained elevated (Table 1) compared with those seen in the antiserumtreated animals (Text-fig. 1b). This confirms the work of Bill (1978) and demonstrates the acute effects of the antiserum. In NRS-treated animals serum progesterone concentrations were similar to those at $0 \mathrm{~h}$ and remained so throughout the 72 -h period. The cause of the lower progesterone levels in the incubation medium when compared to the values for the antiserum treated animals is unknown. It is possible that progesterone in the NRS-treated animals is being converted primarily to oestradiol and that thecal output is diminished.

At 09:00 h of Day 4 (time zero) DNA per follicle was 3.74 $\pm 0.21 \mu \mathrm{g}$ (Text-fig. 1a). The accepted value for mammalian DNA of $6.5 \mathrm{pg} /$ cell leads to an estimated number of $5.75 \times 10^{5}$ cells in the mature PMSG-treated follicle. DNA remained constant during the first $24 \mathrm{~h}$ after induced follicular atresia but was at a nadir by $48 \mathrm{~h}$. The DNA per follicle value of $0.65 \pm 0.08$ $\mu \mathrm{g}$ at $48 \mathrm{~h}$ corresponds to a reduction in cell numbers to $1.0 \times 10^{5}$ cells. At 48 and $72 \mathrm{~h}$ after PMSG antiserum, destruction and elimination of the granulosa compartment was observed histologically (C. J. Hubbard, unpublished). The reason for the slight but significant DNA increase between 48 and $72 \mathrm{~h}$ is unknown but may possibly be due to infiltration of leucocytes or thecal hyperplasia.

Cyclic nucleotides per follicle exhibited a downward trend as atresia progressed. Autoradiographic studies by Uilenbroek, Wourtersen \& van der Schoot (1980) have shown a decrease in FSH and hCG receptors in granulosa cells of atretic follicles during a 4-day period. Both gonadotrophins have been shown to stimulate cAMP synthesis in the hamster (Makris \& Ryan, 1978). A reduction in gonadotrophin receptors may cause a decrease in adenylate cyclase activity, thus explaining the observed cAMP decrease in this study (Text-fig. 1a). Cyclic GMP also decreased during this period, although probably not for the same reasons. Ultimately, the death of the granulosa cells would eliminate adenylate and guanylate cyclases in these cells with a concomitant drop in both cyclic nucleotides. Since the theca interna appeared histologically intact it may still contribute to basal cyclic nucleotide levels. The reason for the inverse fluctuation of cAMP and cGMP between 2 and $4 \mathrm{~h}$ is currently being investigated.

The observed steroid changes agree in some respects with the results of other studies of atresia in antral follicles (Bill, 1978; Hay, Moor, Cran \& Dott, 1979; Braw \& Tsafriri, 1980; Uilenbroek et al., 1980; Terranova, 1981). Using the model described in this paper, and incubating whole hamster ovaries Bill (1978) has shown that oestradiol, testosterone and androstenedione levels decreased over a $24 \mathrm{~h}$ period. Progesterone concentrations (medium + tissue) increased gradually with peak values at $24 \mathrm{~h}$; there was no change in serum progesterone (Bill \& Greenwald, 1979). Hay et al. (1979) found progesterone to be the primary steroid produced in vitro by isolated ovine atretic follicles while normal follicles produced predominantly oestradiol and testosterone. Other studies have shown androstenedione as the 
major product in ovine atretic follicles while oestradiol was highest in normal follicles (Moor, Hay, Dott \& Cran, 1978). Barbiturate-delayed ovulation has also been used to study atretic changes in the antral follicle: Braw \& Tsafriri (1980) and Terranova (1981) observed an increase in progesterone and a decrease in androgen and oestradiol in incubated rat and hamster antral follicles. Uilenbroek et al. (1980) also showed decreases in oestradiol as atresia progressed but progesterone and androgen remained constant or increased.

Several models have been developed to study atresia. These include the use of barbiturates to block ovulation (Braw \& Tsafriri, 1980; Terranova, 1981) and injection of PMSG into immature rats (Peluso, 1979). Since intact animals were used in these studies, some circulating gonadotrophins are always present. In the present study, the withdrawal of gonadotrophin support from the ovary after administration of antiserum to PMSG is presumed to be nearly complete. Consequently the observed changes appear to represent an accelerated pattern of atresia. Following injection of anti-PMSG a rapid and significant decline of oestradiol and androgen occurred in the serum, medium and tissue, while progesterone in the medium and tissue increased and subsequently declined. Histological analysis of the ovary showed an intact but not hypertrophied theca interna (C. J. Hubbard, unpublished). This may explain the constant progesterone levels seen in the medium and tissue following the initial surge period.

The increasing androgen concentrations in atretic follicles observed by previous workers have been attributed to aromatase inhibition (Bill, 1978; Moor et al., 1978). In the present study, however, oestradiol and testosterone fell simultaneously. The addition of testosterone (Braw \& Tsafriri, 1980; Uilenbroek et al., 1980) in vitro has been shown to reverse the inhibition of oestradiol synthesis in atretic follicles. It appears, therefore, that inhibition must occur at some point after progesterone synthesis but prior to aromatization of testosterone. Progesterone also fell after $8 \mathrm{~h}$ in serum, medium and tissue, possibly due to a shift of inhibitory influence to a point prior to progesterone synthesis.

Further studies are needed to determine the respective roles that the granulosa and theca play during the atretic process.

This research was supported by a grant from NIH (HD-00596). C.J.H. was supported by an NIH Research Fellowship (3-F32-HD05821-01S1).

\section{References}

Bill, C.H. (1978) Follicular atresia in the hamster ovary: an endocrinological and morphological study. Ph.D. thesis, University of Kansas.

Bill, C.H. \& Greenwald, G.S. (1979) A model for the study of follicular atresia in the hamster ovary. Biol. Reprod. 20, Suppl. , 46A, Abstr.

Braw, R.H. \& Tsafriri, A. (1980) Follicles explanted from pentobarbitone-treated rats provide a model for atresia. J. Reprod. Fert. 59, 259-265.

Exley, D., Johnson, M.W. \& Dean, P.D.G. (1971) Anti-sera highly specific for $17 \beta$-estradiol. Steroids 18, 605-620.

Giles, K.W. \& Myers, A. (1965) An improved diphenylamine method for the estimation of deoxyribonucleic acid. Nature, Lond. 206, 93.

Greenwald, G.S. (1963) Effect of anti-PMS serum on superovulation in the hamster. Endocrinology 73, 436-441.

Greenwald, G.S. (1973) Effect of anti-PMS serum on ovulation and estrogen secretion in the PMS-treated hamster. Biol. Reprod. 9, 437-446.
Greenwald, G.S. (1979) Analysis of superovulation in the hamster: 1962-1978. Annls Biol. anim. Biochim. Biophys. 19, 1483-1487.

Hay, M.F., Moor, R.M., Cran, D.C. \& Dott, H.M. (1979) Regeneration of atretic sheep ovarian follicles in vitro. J. Reprod. Fert. 55, 195-207.

Makris, A. \& Ryan, K.J. (1978) Cyclic AMP and cyclic GMP accumulation by isolated hamster granulosa cells stimulated by LH and FSH. Acta endocr., Copenh. 89, 173-181.

Moor, R.M., Hay, M.F., Dott, H.M. \& Cran, D.G. (1978) Microscopic identification and steroidogenic function of atretic follicles in sheep. J. Endocr. 77, $309-318$.

Pang, C.N. \& Johnson, D.C. (1974) A method for preparation of steroid-protein antigens for use in immunoassay of steroids. Steroids 23, 203-219.

Peluso, J.J. (1979) In vitro maturation of oocytes collected from atretic follicles. In Ovarian Follicular Development and Function, pp. 85-88. Eds A. R. Midgley \& W. A. Sadler. Raven Press, New York. 
Steiner, A.L., Parker, C.W. \& Kipnis, D.W. (1972) Radioimmunoassay for cyclic nucleotides. $J$. biol. Chem. 247, 1106-1113.

Surve, A.H., Bacso, I., Brinkerhofi, J.H. \& Kirsh, S.J. (1976) Plasma levels of progesterone in pseudopregnant rabbits actively immunized with a progesterone protein conjugate. Biol. Reprod. 15, 343349.

Terranova, P.F. (1981) An estradiol-progesterone shift in atretic follicles of the phenobarbital-treated ham- ster. In Dynamics of Ovarian Function, pp. 35-40. Eds N. B. Schwartz \& M. Hunzicker-Dunn. Raven Press, New York.

Terranova, P.F. \& Greenwald, G.S. (1978) Steroid and gonadotropin levels during the luteal-follicular shift of the cyclic hamster. Biol. Reprod. 18, 170-175.

Uilenbroek, J.Th.J., Wourtersen, P.J.A. \& van der Schoot, P. (1980) Atresia of preovulatory follicles: gonadotropin binding and steroidogenic activity. Biol. Reprod. 23, 219-220. .

Received 26 January 1981 